\title{
Impact of Macroeconomic Factors on the Growth of Islamic Banking: A Case of Pakistan
}

\author{
Shazia Zahid * AB. Basit ${ }^{\dagger}$
}

\begin{abstract}
The present paper attempts to investigate the impact of some selected macroeconomic factors on the growth of Islamic Banking. The Islamic banking is one of the most rapidly growing segment of the economy nowadays particularly in Pakistan and other Islamic countries around the world. Therefore, the aim of our current study is to investigate whether macroeconomic variables influence the growth of Islamic banking in Pakistan or not. For that purpose, we used seven macroeconomic factors such as, gross domestic product, Muslim population, inflation rate, money supply, total savings, interest rates, and remittances. These variables are used because they directly or indirectly influence the Islamic finance system of the country. Annual data spanning from 1985 to 2015 for six Islamic banks were used. After confirming the stationarity and long run association, we estimate model by using error correction model (ECM). Results reveal that Muslim population, GDP growth, money supply and worker's remittances play a positive and significant role in the development of Islamic banking in Pakistan. However, interest rates, savings and inflation are inversely related to the growth of Islamic banks. These empirical findings can have some important policy implications.
\end{abstract}

Keywords: Islamic finance, GDP, money supply, interest rate, inflation, remittances, savings, Pakistan.

\section{Introduction}

Finance is the key factor to run any financial institutions and to provide financial assistance to facilitate the general public. Islamic finance is referred as the activities by which financial enterprises in the Muslim world (banks and other lending institutions), raise capital in accordance with Shariah law. It means all types of investments that are permissible under Islamic law. Islamic finance is defined as products designed by financial institutions to comply with Shariah law (Azwar, 2010; A. Gait \& Worthington, 2008; A. H. Gait \& Worthington, 2007). Islamic financial institutions are those that are based on the objectives, operations and Quran's principles (Ibrahim, 2000; Aman, Sharif, \& Arif, 2016). Islamic financial operations are known and being practised since the 7 th century $\mathrm{AD}$, when the Prophet Muhammad (PBUH) prohibited some transactions involving Riba (interest) under the principle outlined in Quran.

Financial institutions are used as a source of funds to generate finance. Islamic financial institutions also operate various deposits, loans and other commercial services

\footnotetext{
*Lahore Leads University, Lahore, Pakistan. Email: shazabbazil@gmail.com

${ }^{\dagger}$ Professor, Department of Economics, Lahore Leads University, Lahore, Pakistan. Email: abbasitleeds2012@gmail.com
} 
for retail and corporate services. These products and services are underscored as follow: Current Deposit (Al-Wadi'a Principle), Savings Deposits (Al- Mudaraba Principle), Term Deposit (Al-Mudaraba Principle), Saving Bonds (Al- Mudaraba Principle), are used for source of funds by Islamic banks and Musharaka (partnership based upon profit/loss on pre-arranged terms), Mudaraba (Bank supplies the entire capitals to entrepreneurs with a pre-determined profit and any loss), BaiMurabaha (Cost-Plus profit/Mark-up), Bai-Salam (Advance payment-later delivery), Bai-Mu'ajjal (Credit sale), Ijara (Lease finance), Hirepurchase (under Shirakatul Milk, sharing of equity with the client in purchasing some assets), Quard (Interest free loan). These products were developed to safeguard the integrity of money transactions according to Islamic sharia.

Re-monetization of Europe post the Roman Empire and the rebirth of the European banking system owe much to the flow of Muslim coinage to EUROP (Iqbal, 1997). During the Ottoman Empire (1301-1922), global trade grew but Islamic banking was limited (Karim \& Archer, 2013), though it is believed that the first SUKUK was issued in 1775 by the Ottoman Empire when it borrowed money against future income on tobacco customs levies to funds in budget deficit (Cizakca, 2009). The modern journey of development of Islamic finance started with Barclay bank opened in Cairo in Egypt during 1890s to process the financial transactions related to the construction process of Suez Canal. Whereas, modern Islamic economics and finance emerged and recognized in Indo-Pak Muslims by the 1930s. A bank Ahmed-el-Naga in Egypt was founded in 1963. In 1973, Philippine government established a bank on the bases of Islamic sharia. Throughout the 1970s, commercial banking operations using Islamic Financing were the most common type of operations. The establishment of Islamic banking in Malaysia began in 1983 with the establishment of 'Bank Islam Berhad". In 1980's Islamic banks moved into syndication and project financing at different levels in many Islamic and Non-Islamic countries. 1990s and 2000 were the most important decades in global Islamic financing.

The popularity of Islamic banking is increasing due to the flexibility of Islamic principles that was witnessed in global financial crises. Islamic financial industry has grown remarkably at global level, estimated growth rates of these banks were recorded as $10 \%$ to $15 \%$ during 1995 to 2005 (M. S. N. Khan, Hassan, \& Shahid, 2007). The Global Islamic assets held by commercial banks stood at \$1.3bn in 2011, but the industry's forecast growth of around $40 \%$ over two years will push this figure to \$ $1.8 \mathrm{bn}$ in 2013 (Young, 2013; Belouafi \& Chachi, 2014). According to Young (2013), Islamic finance is growing at the rate of $15 \%-20 \%$ per annum. The growth of Islamic banking system is faster than $50 \%$ overall banking system in core markets. Islamic banks are operating in more than 83 counties including Muslim counties as well as non-Muslim countries (Nahar \& Sarker, 2016). In addition to Islamic banking, Islamic wealth management (IWM) is one of the fastest-growing financial segments in the global Islamic financial industry. According to State Bank of Pakistan (2017), there are 21 banks in Pakistan involved in Islamic finance with a network of around 2,133 branches across country. The total global Islamic assets under wealth management reached at 58 billion US $\$$ and the number of Islamic funds stood more than one thousands, declared by SBP (State Bank of Pakistan) as of December, 2015. In Pakistan, Islamic banking industry since its re-launched in 2002 has shown significant progress in the country. At present, the Islamic banking industry has attained 
11.4 percent and 13.2 percent share respectively in the total assets and deposits of overall banking industry (Bulletin, 2016). State Bank of Pakistan has played an important role in providing favorable environment and enabled the industry to become the part of growth and introduced a comprehensive legal and Shariah compliance framework for the Islamic Banking Industry (Bulletin, 2016). Pakistan took a new start for Islamic banking and finance in 2002. Meezan bank was established as premier Islamic bank. Pakistan is operating as a dual banking system and the Islamic banking industry is facing high competition in the market in the area of financing. The reason behind the study is dependency of Islamic banking industry on deposits, changing attitude of savers and investors regarding investment decisions, high competition in the industry, changing country's economic conditions, and dynamics of market. However, the current study has focused only on macroeconomic factors which influence the growth of Islamic finance with respect to Islamic banking industry of Pakistan.

In the context of Pakistan, scarce literature is available on the relationship of macroeconomic variables with Islamic finance focusing on Islamic banking industry. Therefore, this study aims to bridge the gap in the existing literature.

\section{Literature Review}

The financing modes and approaches of Islamic finance (without interest) are entirely opposite and different from conventional financing (with interest) in the economy. The fundamental principle beneath the Islamic financial system is based on partnership (Chapra, 2000; Ahmed, 2000; Wilson, 1995). As there is a group of macro-economic variables impacting the growth of Islamic finance, so we have proceeded to review available rare literature in this regard. Previous studies conducted in this area, mainly focused on some modes of Islamic finance, issues \& challenges being faced by Islamic banking industry and economic growth. These are very important factors for development of Islamic financial system because growth demands finance. Development in Islamic banking stimulates growth, are conceptual factors that affect the development of Islamic finance from the beginning. Changes in law and regulations, the restructuring process and governmental support policies, foreign direct investment (FDI), money supply (M2) and Murabaha to the Purchase-Order (MPO), inflation rate, and exchange rate have highly significant relation with Islamic Bank Financing (Farahani, 2012; Dhankar, 2014; Curuk, 2014; Ahmad, Yazis, \& Oudat, 2015; Nahar \& Sarker, 2016). However, there are few studies which are done on the impact of population and relative importance of Islamic finance and banking. In the Muslim populated countries, there is substantial potential for Islamic finance because it can fund by borrowers and moving lenders from the informal to formal financial market.

Presence of Islamic banks as financial providers will be influential particularly in large Muslims populated countries. They estimated a positive and significant relationship between population growth and Islamic financial development and found some evidence in support of poverty alleviation particularly in rural areas (Abedifar, Hasan, \& Tarazi, 2015; Abedifar, Molyneux, \& Tarazi, 2013; Cizakca, 2009; Honohan, 2008). An interesting 
and significant study was drawn from the study of Johnson (2013), regarding the limited economic growth by expansion of Islamic financial institutions and Muslims pervasiveness in the population of a country was found to be most significant determinant of the dissemination of Islamic finance and suggested that some of the effects of convergence may operate through adaption of Islamic finance. The most relevant and stimulus from the studies indicated the monetary policy variables (money supply, interest rate \& GDP) and Islamic banks deposits (case study of Islamic banks of Bahrain \& Malaysia) (Ihsan \& Anjum, 2013). Similarly, in the case of Nigeria, the principle components i-e interbank call rate, inflation, and monetary policy rates are three components which have significant variability in M2. Whereas inflation, monetary policy rate, saving deposit rate, and treasury bill rate have also impacted on M2 in Islamic financing (Oni, Emoh, \& Ijasan, 2012). Ahmad et al. (2015) did a case study in Jordan; these researchers observed some analysis on the relationships between macro-economic variables Gross Domestic Product (GDP), Foreign Direct Investment (FDI), money supply (M2) and (MPO) Murabaha to the Purchase-Order.

Interest rate of conventional banks plays an important role in generating finance and increase in deposit shares of Islamic finance. Kader (2009) found that change in interest rate is caused in the demand for Islamic bank financing and the period specifically after the Asian financial crisis when interest rates were falling. Kassim, Majid, and Shabri (2009) examined the similar impact of monetary policy shockwaves on Islamic financing and conventional loaning in Malaysia and influence of monetary policy shockwaves by govt. in a dual banking (conventional and Islamic banks) system. The responses of the conventional banks and Islamic banks towards monetary policy shock were different. To provide meaningful comparison, the same analysis was performed for both Islamic and conventional banks. The results of the study showed that the Islamic banks' items on the balance sheet are more sensitive to the changes in monetary policy. In the study of Kasri (2010), deposits of Islamic banks were expected to be influenced by total number of branches of Islamic banks, real income, real rate of return and real interest rate of conventional banks. Likewise, Adebola (2011), picked Malaysia and investigated the impact of interest rate (conventional bank) on the volume of financing of Islamic banks. They concluded that Islamic banks financing is complementary rather than substitute to conventional banks. In addition, financing and interest rate have negative impact on Islamic banking financing. Rab (2004), observed the devaluation of currency and its use as unit jeopardizes the ability of sharing of profit (Mudarabah) to do justice to the capital owner (Rab-al-mal). It results in transferring the gains (real) to the entrepreneur (Mudarbah) in agreed proportion and feasibility of these modes of finance is essential for ensuring the proper utilization of Islamic finance. In the studies conducted by Abduh (2011), for Malaysia, (Al-Fawwaz, Alawneh, \& Shawaqfeh, 2015), for Jordan (Nahar \& Sarker, 2016), a negative correlation between Islamic finance and inflation rate is existed. According to them, Islamic finance increases production of goods \& services in the economy and it decreases the prices of general goods and services in the economy. Savings are considered as backbone of an economy. They play a vital role in raising bank reserves (deposits) and further financing to accumulate capital. Mushtaq and Siddiqui (2016), affirmed that the two most important macroeconomic tools, Saving and investment play a major role 
in economic growth. The objectives of their study was to evaluate the effects of Shariah based parameters on the financial decisions for savings and further investment for an Islamic country's population. They did comparison by taking data of 17 Islamic and 17 non-Islamic countries from 2005-2013 by using the random effect and GMM model (system generalized method of moments). A. H. Khan, Hasan, and Malik (1994), observed the determinants of saving rate by using diversity of factors for Pakistan. They assessed a sturdy effect of per capita GNP on the national savings of Pakistan and concluded that openness of the economy directly influences national savings where real interest rate will change in terms of trade. Whereas, debt to GNP ratio and dependency ratio have contrary effects on national saving. Khalid (2004), concluded in their study that per capita GNP positively and strongly effect the national saving. In Pakistan, savings do not affect government budget deficit significantly whereas remittances received to government play a necessary part to increase the saving's level in the country. Akhtar, Akhter, and Shahbaz (2017), investigated Pakistan for the influence of major selected macroeconomic variables on the deposits of conventional and Islamic banks. The researchers took quarterly data of Six years from 2006 to 2010 of 30 banks consisting of 25 conventional and 5 Islamic banks. The authors concluded that deposits of conventional and Islamic banks, BLR, CPI, KIBOR, M3 and PR have significant long-run relationship with the total deposits of both conventional and Islamic banks.

Remittances are a perceptible part of government reserves in an economy. Only few studies can be found in this area of research. Khalid (2004), investigated and concluded that remittances contribute positively towards the higher national savings in the country and savings in the country like Pakistan, not significantly affected by the budget deficit and government investment. Mostly researchers have applied ADF test to check stationary of the variables, co-integration for long run relationship and applied ECM model to check the short run changes in equilibrium. Our study will test the hypotheses derived from literature reviewed, that are expected to check the impact of our selected variables on the growth of Islamic Finance.

Many macroeconomic variables influence the financial structure and market in any country. As it is proposed, that if there is good economic condition with maximum working labor and higher level of saving and investment will ensue with higher level of growth of finance. Being focused on the growth of Islamic finance, interest rate of conventional banks and inflation rate shall work with inverse intensity. With the help of research articles and proposed model, following hypotheses were developed for the study.

\section{$H_{1}$ : Economic growth has a positive impact on the growth of Islamic banking.}

Islam is the main objective behind the selecting Islamic finance. When all the financial services will be provided according to sharia compliance, there will be great motivation for the Muslim people to take non-interest financial transactions, continuous development and knowledge for the creation of Islamic financial services based on profit sharing (Equity partnership). It's a bidirectional relationship.

$\mathrm{H}_{2}$ : Muslim population has a positive impact on the growth of Islamic banking. 
Due to religious perspective, highly Muslim populated countries which prefer sharia compliant financial product and services will improve economic welfare i-e economic growth, income inequality and poverty alleviation with higher uncertainty or comparatively low GDP per capita.

$H_{3}$ : Money supply has a positive impact on the growth of Islamic banking.

When the total amount of available monetary assets is stable and increased in the economy, there is an availability of finance to invest in the society. Better money supply initiate money circulation in the economy.

$H_{4}$ : Real interest rate has a negative impact on the growth of Islamic banking.

Interest rate (conventional bank) leaves an inverse impact on the volume of financing of Islamic banks. All customers are profit oriented and they expect real rate of return on their deposits. When there is an increase in conventional bank interest rate, real rate of return on deposits will move down and customers will switch towards Islamic banking and as a result level of Islamic deposits will rise, so real interest rate has negative relation with Islamic deposits.

\section{$H_{5}$ : Inflation rate has a negative impact on the growth of Islamic banking.}

Inflation rate is measured by consumer price index and the general increase in price will result in less purchasing of the consumer. So, real level of savings, investment and wealth reduces. High level of inflation causes non-equality in distribution of income Inflation from lenders to borrowers and from employers to employees when salaries are not adjusted for inflation.

\section{$H_{6}$ : Savings has a positive impact on the growth of Islamic banking.}

Higher growth rate inclines the people of Islamic countries to save more. This behavior of Muslims is explained as that the Muslims are persuaded to save rather than to spend lavishly; Savings are basic source of financing capital and financial assets in the economy. According to classical economist, people tend to decrease their present when the latter (future earnings) is high, reduce consumption and save more. It stimulates economic activities. Greater ratio of savings promotes economic growth in the country.

\section{$H_{7}$ : Remittances has a positive impact on the growth of Islamic banking.}

The foreign-exchange earnings are the major source of improvement in the volume of reserves of the country which are said to be the compensation of the migrants and employees in the foreign country. When it increases, becomes the cause of raising the country reserves. 


\section{Methodological Framework}

To uncover the effect of macroeconomic factors on the Islamic Banking of Pakistan, we have used annual data of six Islamic banks covering the time period from 1985 to 2015. All the data are obtained from distinct sources such as, Economic survey of Pakistan, Islamic banking bulletin, state bank of Pakistan, and World development indicator, IMF and World bank.

\section{Variables Description}

In our study, we have selected some macro-economic variables. This section narrates and explains these variables. Determinant of these variables are done on the basis of previous studies. There is one dependent variable (Islamic finance) and seven independent variables (GDP, Muslim population, money supply, interest rate, inflation rate, savings, remittance. Growth of Islamic finance was measured by modes of Islamic finance (Dhankar, 2014; Al-Fawwaz et al., 2015) which are Murabaha, Ijara, Musharaka, Mudarabah, Diminishing Musharaka, Salam, Istisna, and Qarz-e-Hansna. Economic growth was measured by gross domestic product (GDP). Population growth was measured by Muslim population growth rate. Money supply was measured by MII (Ahmad et al., 2015). For interest rate of conventional bank, interest rate which was announced by state bank of Pakistan was taken. Inflation rate was measured by consumer price index (CPI) (Nahar \& Sarker, 2016). Savings have been taken by taking total sum of public and private savings. Remittances are measured by taking annual growth rate. Then, we have presented all selected variables in the model and its measurements.

\section{Research Method}

An annual time series for Pakistan covering the period from 1985-2015 was used. Tentatively we could get some clues, if these were plotted, but it was necessary to know the statistical or stochastic mechanism that generated this data, each of the variables of our study was a random variables or stochastic process as its series was a particular realization of that process. For this co- integration, consider the dominant requirement or the estimation of an economic model by using non-stationary time series data. So stationary of this variable is to ensure before putting them into further analysis. To officially check the stationarity of series, the Unit Root Test is commonly adapted to test and it is also known as modern method to check stationary. It was presented by Dickey and Fuller $(1979,1981)$. This test simultaneously checks the data is non- stationarity and there is Unit Root which is present in the variables. To empirically test the long-run relationship among the variables, ECM (error correction model) approached to co-integration has been applied.

The empirical model used for the study can be expressed as follows; 


$$
G I F_{i t}=\alpha_{o}+\alpha_{1} G D P_{i t}+\alpha_{2} P G_{i t}+\alpha_{3} M 2_{i t}+\alpha_{4} I R_{i t}+\alpha_{5} C P I_{i t}+\alpha_{6} R E M_{i t}+\alpha_{7} S A V_{i t}+\lambda_{t}
$$

Where, GIF is the growth of Islamic finance (banks), GDP is the gross domestic product used as a proxy for economic growth. PG is the Muslim population growth, M2 is the broad money supply, CPI is the consumer perception index used to measure the inflation rate of the economy. IR denotes as the interest rate, REM is the worker's remittances, SAV is the total savings and lastly the subscript $t$ and i represent the total number of time period and total number of banks used in the study.

\section{Empirical Results}

\section{Unit Root Test}

Unit root test checks is to use stationarity of the data. If the data is non-stationarity, the regression estimates may become spurious. Augmented Dickey-Fuller (ADF) test has been used to check stationarity property of data. The results showed that the variables were non stationary at $\mathrm{I}(0)$, however, they were found to be stationary at $\mathrm{I}(1)$. The results of ADF Unit root test are presented in Table 1.

Table 1

\begin{tabular}{|c|c|c|c|c|c|c|c|c|}
\hline \multirow[t]{3}{*}{ Variable } & \multicolumn{4}{|c|}{ I (0) } & \multicolumn{4}{|c|}{ I (1) } \\
\hline & $\mathrm{C}$ & & $C \& T$ & & $\mathrm{C}$ & & $C \& T$ & \\
\hline & t-stats & Prob & t-stats & Prob & t-stats & Prob & t-stats & Prob \\
\hline IF & 1.951 & 1.000 & 3.326 & 0.081 & 7.931 & 0.000 & 8.438 & 0.000 \\
\hline GDP & 3.607 & 1.000 & 0.082 & 0.996 & 3.274 & 0.026 & 4.825 & 0.003 \\
\hline MPOP & 1.040 & 0.726 & 2.116 & 0.517 & 5.355 & 0.000 & 5.283 & 0.001 \\
\hline M2 & 0.151 & 0.963 & 0.810 & 0.951 & 1.145 & 0.000 & 3.045 & 0.013 \\
\hline IR & -1.830 & 0.360 & -1.822 & 0.669 & -4.538 & 0.001 & -4.669 & 0.004 \\
\hline CPI & -2.862 & 1.000 & -2.739 & 0.230 & -1.685 & 0.000 & -5.569 & 0.001 \\
\hline SAV & 1.704 & 0.999 & 0.689 & 0.965 & 5.119 & 0.003 & 6.028 & 0.000 \\
\hline REM & 2.384 & 0.155 & 2.200 & 0.472 & 3.944 & 0.005 & 4.701 & 0.000 \\
\hline
\end{tabular}

\section{Cointegration Test}

On the basis of Augmented Dickey Fuller (ADF) test, it was found that all of the variables in the model are integrated at first difference. In other words, we can say that order of integration remains same for all variables. In such case, Johanson co-integration is a suitable technique to find out long-run relationship among the variables. The results of Johanson's estimation are presented in the table 2. The rank test (Eigen value) indicated the same as the trace test (trace). We emphatically rejected the null hypothesis of series at $5 \%$ level. 
Table 2

\begin{tabular}{lcccccc} 
Johansen Cointegration Test & & & & \\
\hline $\begin{array}{c}\text { Co-integrating } \\
\text { Vectors }\end{array}$ & $\begin{array}{c}\text { Trace } \\
\text { Statistics }\end{array}$ & $\begin{array}{c}\text { Critical } \\
\text { value at 5\% }\end{array}$ & Prob. & $\begin{array}{c}\text { Max Eigen } \\
\text { statistics }\end{array}$ & $\begin{array}{c}\text { Critical } \\
\text { value at 5\% }\end{array}$ & Prob. \\
\hline None & 168.178 & 58.433 & 0.000 & 511.128 & 197.37 & 0.000 \\
At most 1 & 115.976 & 52.362 & 0.000 & 342.949 & 159.53 & 0.000 \\
At most 2 & 72.824 & 46.231 & 0.000 & 226.974 & 125.615 & 0.000 \\
\hline \multicolumn{2}{l}{ Source: Authors' Estimation } & & & & &
\end{tabular}

\section{Error Correction Model (ECM)}

We applied Error Correction Model (ECM) to check short run dynamics among selected macro-economic variables and growth of Islamic banking. This model exposed that in what period and at what speed dependent variable returns to its balancing point / level after bringing change in independent variables. The estimates of ECM model have been given in Panel A of Table 3. It represents the time limit and speed of dependent variable coming back to its equilibrium and the negative sign represents the change in the long run model. From the previous result, the existence of co integration in our data has been verified. The impact of independent variable in short run behavior of Islamic banking cannot be depending upon the long run coefficients only. To examine this effect, we have applied the ECM to locate the short run dynamics.

An equilibrium correction mechanism required that the short run error correction term to be negative which assure the reversion to equilibrium as present in the table 4.5.1.

The estimated value of ECM is -0.752 which proves the presence of dynamic relationship between variables. The coefficient of ECM (-1) show how fast the variables are moving to the long run equilibrium after short run shocks. Lon run equilibrium can be obtained when the ECM coefficient has negative sign and statistically significant at $95 \%$ level. This coefficient suggests the $75 \%$ error will be adjusted in first period. It points to relatively fast speed of adjustment. The variables are significantly impacting the adjustment towards long run equilibrium.

The Panel B of Table 3 shows the long run regression estimates of the model. The results clearly indicated that co-efficient of GDP, MPOP, M2, CPI, and REM are highly statistically significant. The coefficients of IR, and SAV an insignificant at $5 \%$. The estimated parameters indicate that there have been existed long run relationship among the variables. Although, variables, IR and SAV are statistically insignificant but their economic significance cannot be ignored. Coefficient of GDP is indicating that GDP has direct but significant influence on growth of Islamic Finance When, GDP of the county increases, it causes growth of economic activity in the country. Coefficient of regression of Muslim population has positive relation with growth of Islamic finance and if Muslim population will increase to even 1\%, then, Islamic finance will grow (increase) by Rs.0.331 billion and vice versa. Thus, it is accepted that population growth rate has positive and significant impact on growth of Islamic finance with respect to Islamic banking industry of the country. 


\begin{tabular}{lccc} 
Table 3 \\
Error Correction Model and Long Run Estimates \\
\hline \multicolumn{4}{c}{ Panel A: Short Run ECM Estimates } \\
\hline Variable & Coefficient & t-stats & Prob. \\
\hline C & 51.418 & 0.324 & 0.749 \\
D(GDP) & 50.827 & 6.469 & 0.000 \\
D(M2) & 2.132 & 6.394 & 0.000 \\
D(IR) & -56.286 & -1.928 & 0.590 \\
D(CPI) & -30.212 & -0.955 & 0.035 \\
D(MPOP) & 0.796 & 0.202 & 0.058 \\
D(SAV) & 0.093 & 0.365 & 0.719 \\
D(REM) & 229.603 & 3.076 & 0.006 \\
ECM(-1) & -0.753 & -9.550 & 0.000 \\
\hline \multicolumn{5}{c}{ Panel B: Long Run Estimates } \\
\hline GDP & 32.549 & 3.089 & 0.005 \\
M2 & 1.532 & 3.289 & 0.003 \\
IR & -61.441 & 1.448 & -0.161 \\
CPI & -55.91 & -2.519 & 0.016 \\
MPOP & 0.331 & 2.955 & 0.003 \\
SAV & 0.147 & 0.325 & 0.747 \\
REM & 172.51 & 2.614 & 0.015 \\
\hline Source: Author's Estimation
\end{tabular}

Coefficient of (M2), money supply is indicating that if more money will be in circulation, financing of Islamic banks will increase with Rs.1.532 billion and vice versa. So hypothesis should be accepted. Thus, it is accepted that money supply has a positive and significant impact on growth of Islamic finance with respect to Islamic banking industry of the country.

Coefficient of IR has negative relation between interest rate and growth of Islamic finance. When interest rate of commercial banks increases, finance of Islamic banks grows inversely. So, interest rate increases $1 \%$, volume of Islamic finance will decrease by Rs. 61.441 billion in the country. So interest rate of conventional banks leaves negative but insignificant impact on growth of Islamic finance.

Coefficient of inflation rate (CPI) has negative influence on Islamic banking financing. As there is $1 \%$ increase in inflation rate, growth of Islamic finance will be weakened by Rs. 55.91 billion. That is indicating that CPI has inverse but significant relationship with growth of Islamic finance. Savings play a vital role in generating finance and significant part of investment in the country. In our findings, it has a positive but insignificant relationship with the growth of Islamic finance where there will be $1 \%$ change in savings, Islamic finance will increase by 0.147 billion. Foreign remittance plays an important role in a countries economic growth and raise government reserves for providing finance. By implying good policies, a country's government can boost the economic activities in the country. If there is $1 \%$ increase in REM, Islamic finance will raise by 172.51 billion.

\section{Conclusion and Recommendations}

This study scrutinized and examined the impact of our selected major macroeconomic variables on the growth of Islamic banking. The data was taken from 1985-2015.To determine the long run effects and short run influence on the growth of Islamic banking, the co- 
integration approaches to ECM models were applied to analyze the empirical data. The selected macroeconomic determinants of Islamic banking were GDP (economic growth), MPOP (Muslim population), M2 (money supply), CPI (inflation rate) and IR (interest rate), SAV (savings) and REM (remittance). Our findings substantiate a considerable long run relationship between Islamic banking and other all independent variables. Our results are in the accordance with previous researches. Co-integration results suggest that GDP has positive but significant relationship with volume of Islamic banking. This behavior of Muslims is explained as that lavishly spending is prohibited in Islam as it stated in Quran clearly. Islamic banking industry should accommodate more P\& L products in order to be more interest free. Documentation of Islamic banking should be convenient so that more and more people with less income can deal with banks running Islamic banking system. While M2, has a positive and significant relation with the growth of Islamic banking. The state bank of Pakistan (SBP) holds and manages the monetary policy in the Pakistan. Being an important tool of monetary policy, change in M2 will change the supply of money and affect the country's economic condition. Country specially believe in Islamic sharia should investigate and invest in socially good, trusted and socially recognized companies. By which, overall capital size and reputation of transaction increases. M2 has negatively impacted on the deposit of conventional banks but have a positive influence on the deposits of Islamic finance. As a result, there will be a great motivation for the people to choose Islamic banking to maintain their deposits. In our study, we found out that REM have direct (positive) and significant relation with the growth of Islamic finance. Remittances received to the country should imply to increase investment in productive zones. Remittances can contribute towards higher savings in the country if more effective policies are implied for transferring of remittances and in creation of further jobs for Pakistanis abroad. Improvement / enhancement of inflation rate (when CPI is an indicator), will decrease the growth of Islamic finance and vice versa and CPI has an inverse but a significant impact on the growth of Islamic finance. Islamic finance promotes investment, savings and business activities on profit and a loss basis and general price of goods and services are adjusted at lower level. Being religion as a factor, demand of Islamic finance is greater in Islamic countries because Muslim population of the Muslim country prefers to finance according to their religious belief. Muslim population growth increases demand for Islamic modes of finance (Shariah compliance products). Normally customers are profit oriented as well as want to get safety of their finance and when interest rates of the conventional banks increase customer of Islamic populated countries leave obtaining loans from commercial banks and prefer to move towards Islamic financing because RIBA (interest) is prohibited in Islam. Our results show that interest rate of conventional banks has inverse effect on the total reserves of Islamic finance. Islamic bank deposits rise with an increase in the rate of returns and decrease in rate of interest. The study validates the results that a rise in conventional banks financing rate (profit rate) will decrease both conventional banks' lending and Islamic banks financing. Savings and remittances are two main components of financial assets and reserves of financial institution. In our results SAVING has positive but insignificant relationship and REM has positive and significant impact on Islamic finance. Saving and investment are the main tools for economic growth; it is attributed with good planning. Muslim countries should give importance to interest 
rate, they should try to increase per capita income of the country and reduce national expenditures by cut down extra spending. The findings of the study have an important implication on the Islamic banking industry in Pakistan and Islamic banking industry has to understand the preference (attitude) of investors. 


\section{References}

Abduh, M. O. (2011). The impact of crisis and macroeconomic variables towards islamic banking deposits. American Journal of Applied Sciences, 8(12), 1378-1383.

Abedifar, P., Hasan, I., \& Tarazi, A. (2015). Finance-growth nexus and dual-banking systems: Relative importance of islamic banks. SSRN Electronic Journal.

Abedifar, P., Molyneux, P., \& Tarazi, A. (2013). Risk in islamic banking. Review of Finance, 17(6), 2035-2096.

Adebola, S. S. (2011). The impact of macroeconomic variables on Islamic banks financing in Malaysia. Research Journal of Finance and Accounting, 2(4), 22-32.

Ahmad, N., Yazis, M., \& Oudat, M. S. (2015). Analysing long-run and short-run relationships between macroeconomic variables and murabaha to the purchase-order: Evidence from Jordanian islamic bank. International Journal of Economics and Finance, $7(2), 168$.

Ahmed, S. A. (2000). Global need for a new economic concept: Islamic economics. International Journal of Islamic Financial Services, 1(4), 13-27.

Akhtar, B., Akhter, W., \& Shahbaz, M. (2017). Determinants of deposits in conventional and Islamic banking: A case of an emerging economy. International Journal of Emerging Markets, 12(2), 296-309.

Al-Fawwaz, T. M., Alawneh, A. M., \& Shawaqfeh, G. N. (2015). The impact of islamic finance on some macro economic variables (A case study of Jordan islamic bank). Interdisciplinary Journal of Contemporary Research in Business, 7(1), 10-30.

Aman, A., Sharif, S., \& Arif, I. (2016). Comparison of Islamic banks with conventional banks: Evidence from an emerging market. Journal of Management Sciences, 3(1), 24-33.

Azwar, A. (2010). Islamic finance course: Structure $\mathcal{E}$ instruments. Wan Ashraf at SCRIBD.

Belouafi, A., \& Chachi, A. (2014). Islamic finance in the United Kingdom: Factors behind its development and growth. Islamic Economic Studies, 22(1), 37-78.

Bulletin, I. B. (2016). Islamic banking bulletin. State Bank of Pakistan. Retrieved from http://www.islamicbankingbukketinSBP.PK.

Chapra, U. (2000). Why has islam prohibited interest: Rationale behind the prohibition of interest. Review of Islamic Economics, 9(1), 5-20.

Cizakca, P. M. (2009). http://www.bankislam.com.my/en/documents-amana bank. Retrieved from http:/ / www.bankislam.com.

Curuk, S. A. (2014). Factors effecting the development of islamic finance in Turkey.

Dhankar, T. (2014). Islamic finance and economic growth: An empirical evidence from United Arab Emirates (UAE). Journal of Emerging Issues in Economics, Finance and Baking, 3(2). doi: ISSN:2306-367X

Farahani, G. Y. (2012). Analysis of islamic bank's financing and economic growth: Case study Iran and Indonesia. Journal of Economic Cooperation $\mathcal{E}$ Development, 33(4), 1-24.

Gait, A., \& Worthington, A. (2008). An empirical survey of individual consumer, business firm and financial institution attitudes towards islamic methods of finance. International Journal of Social Economics, 35(11), 783-808. 
Gait, A. H., \& Worthington, A. C. (2007). A primer on Islamic finance: Definitions, sources, principles and methods. University of Wollongong School of Accounting and finance working paper.

Honohan, P. (2008). Cross-country variation in household access to financial services. Journal of Banking $\mathcal{E}$ Finance, 32(11), 2493-2500.

Ibrahim, W. (2000). Islamic Finance in the Global Economy. Edinburgh University Press.

Ihsan, I., \& Anjum, S. (2013). Impact of money supply (M2) on GDP of Pakistan. Global Journal of Management and Business Research, 13(6), 1-8.

Iqbal, Z. (1997). Islamic financial systems. Finance and Development, 34(2), 42-45.

Johnson, K. (2013). The role of Islamic banking in Economic growth. Claremont McKenna College.

Kader, R. (2009). The impact of interest rate changes on islamic bank financing. International Review of Business Research Papers, 5(3), 189-201.

Karim, A., \& Archer, S. (2013). Islamic finance: The new regulatory challenge. John Wiley \& Sons.

Kasri, R. (2010). The determinants of Islamic banking growth in Indonesia. International Review of Business Research Papers, 6(2), 41-64.

Kassim, S., Majid, A., \& Shabri, M. (2009). Impact of monetary policy shocks on the conventional and islamic banks in a dual banking system: Evidence from Malaysia. Journal of Economic Cooperation and Development, 30(1), 41-58.

Khalid, N. (2004). Saving-investment behaviour in Pakistan: An empirical investigation. The Pakistan Development Review, 43(4), 665-682.

Khan, A. H., Hasan, L., \& Malik, A. (1994). Determinants of national saving rate in Pakistan. Economia Internazionale/International Economics, 47(4), 365-382.

Khan, M. S. N., Hassan, M. K., \& Shahid, A. I. (2007). Banking behavior of islamic bank customers in Bangladesh. Journal of Islamic Economics, Banking and Finance, 3(2), 159194.

Mushtaq, S., \& Siddiqui, D. A. (2016). Effect of interest rate on economic performance: Evidence from islamic and non-islamic economies. Financial Innovation, 2(1). doi: 10.1186/s40854-016-0028-7

Nahar, S., \& Sarker, N. (2016). Are macroeconomic factors substantially influential for Islamic bank financing? Cross-country evidence. Journal of Business and Management, 18(6), 20-27.

Oni, A., Emoh, F., \& Ijasan, K. (2012). The impact of money market indicators on real estate finance in Nigeria. Sri Lankan Journal of Real Estate(6), 16-37.

Rab, H. (2004). Impact of inflation on mudarabah profits: Some observations. Islamic Economics, 17(2), 21-25.

Wilson, R. (1995). Marketing strategies for Islamic financing products. New Horizon, 39(1), $7-9$.

Young, E. (2013). Report on Global Islamic Assets. EY's Global Islamic Banking Centre. 